\title{
HUBUNGAN KELAINAN REFRAKSI DENGAN PRESTASI BELAJAR ANAK DI SMP KRISTEN EBEN HAEZAR 2 MANADO
}

\author{
Nandy E. Rumondor \\ Laya M. Rares
}

\begin{abstract}
Bagian Ilmu Kesehatan Mata Fakultas Kedokteran Universitas Sam Ratulangi Manado Email : nandy_edverson@yahoo.com
\end{abstract}

\begin{abstract}
Eye health in school students is one of the important factors that determining the learning achievement. Refractive disorders can disturb the information process while studying. This study aimed to determine the relation between refractive disorders with students learning achievement. This was an observational research with cross sectional design and the studied problems occur by itself without intervention from the researcher. There were 50 respondents from VIII grade students of SMP Kr. Eben Haezar 2 Manado, taken from simple random sampling. The result of this study showed that students with refractive disorders $(p=0,01, p<0,05)$ were significantly related with students learning achievements. Conclusion refractive disorders were significantly related with students learning achievement.
\end{abstract}

Keywords: refractive disorders, learning achievement

\begin{abstract}
Abstrak: Kesehatan mata pada anak di usia sekolah menjadi salah satu faktor yang penting dalam menentukan prestasi belajar. Dengan adanya kelainan refraksi dapat mengganggu proses penerimaan informasi anak saat belajar. Tujuan dari penelitian ini adalah untuk mengetahui hubungan kelainan refraksi dengan prestasi belajar anak. Metode penelitian yang digunakan adalah potong lintang dengan sifat observational dan masalah yang diteliti terjadi dengan sendirinya tanpa intervensi dari peneliti. Sampel penelitian adalah anak SMP Kr. Eben Haezar 2 Manado kelas VIII berjumlah 50 orang yang diambil secara acak. Hasil penelitian ini menunjukkan penderita kelainan refraksi ( $p=0,01, p<0,05$ ) berhubungan secara signifikan dengan prestasi belajar. Simpulan kelainan rerfraksi berhubungan secara signifikan dengan prestasi belajar.
\end{abstract}

Kata kunci: kelainan refraksi, prestasi belajar

Kelainan refraksi merupakan salah satu kelainan mata yang paling sering terjadi. Saat ini kelainan refraksi masih merupakan masalah kesehatan masyarakat di dunia. Tiga kelainan refraksi yang paling sering dijumpai yaitu miopia, hipermetropia, dan astigmatisma. Jenis kelainan refraksi yang keempat yaitu presbiopia. ${ }^{1} \mathrm{Di}$ Indonesia prevalensi kelainan refraksi menempati urutan pertama pada penyakit mata. Kasus kelainan refraksi dari tahun ke tahun mengalami peningkatan. Jumlah pasien yang menderita kelainan refraksi di Indonesia hampir 25\% dari populasi atau sekitar 55 juta jiwa. ${ }^{2}$ 
Berdasarkan data dari WHO pada 2004 prevalensi kelainan refraksi pada umur 5-15 tahun sebanyak 12,8 juta orang $(0,97 \%){ }^{3}$ Dari data tersebut ditemukan bahwa kelainan yang timbul akibat kelainan refraksi yang tidak di koreksi. Melihat situasi yang ada WHO merekomendasikan untuk dilakukannya skrining penglihatan dan pelayanan kesehatan yang ditujukan bagi anak sekolah. ${ }^{4-6}$ Berkaitan dengan hal tersebut maka pada anak usia sekolah tingkat taman kanak-kanak sampai sekolah menengah tingkat pertama sangat rentan terhadap kelainan refraksi apabila sedini mungkin tidak di koreksi akibatnya akan berpengaruh pada kegiatan belajar dan dapat mempengaruhi prestasi belajar.

\section{KELAINAN REFRAKSI}

Kelainan refraksi mata adalah suatu keadaan dimana bayangan tegas tidak dibentuk pada retina tetapi di bagian depan atau belakang bintik kuning dan tidak terletak pada satu titik yang tajam. Kelainan refraksi dikenal dalam bentuk miopia, hipermetropia, dan astigmatisma. ${ }^{1}$

\section{MIOPIA}

Miopia atau rabun dekat adalah suatu kelainan refraksi pada mata dimana bayangan difokuskan di depan retina, ketika mata tidak dalam kondisi berakomodasi. Ini juga dapat dijelaskan pada kondisi refraktif dimana cahaya yang sejajar dari suatu objek yang masuk pada mata akan jatuh di depan retina. ${ }^{7}$

Beratnya miopia dapat di klasifikasikan sebagai berikut : (1) Miopia ringan $<-2.00$ dipotri, (2) Miopia sedang -2.00 hingga -6.00 dioptri, (3) Miopia berat -6.00 hingga -9.00 dioptri, (4) Miopia sangat berat $>-9.00$ dioptri. Miopia dapat diobati dengan menggunakan lensa negatif atau biasa juga disebut lensa konkaf / divergen.

\section{HIPERMETROPIA}

Hipermetropia atau far-sightedness adalah suatu kelainan refraksi daripada mata dimana sinar-sinar yang berjalan sejajar dengan sumbu mata tanpa akomodasi dibiaskan di belakang retina. Untuk mengoreksinya dipakai lensa positif atau konveks / konvergen.

\section{ASTIGMATISMA}

Astigmatisma adalah suatu keadaan dimana sinar yang sejajar tidak dibiaskan dengan kekuatan yang sama pada seluruh bidang pembiasan sehingga fokus pada retina tidak pada satu titik. ${ }^{1}$ Ada dua jenis astigmatisma, yaitu astigmatisma regular dan astigmatisma irregular. Astigmatisma regular dapat di klasifikasikan sebagai berikut : (1) Simple astigmatism, (2) Compound astigmatism, (3) Mixed astigmatism.

\section{PRESTASI BELAJAR}

Prestasi belajar adalah suatu bukti keberhasilan belajar atau kemampuan seseorang siswa dalam melakukan kegiatan belajarnya sesuai dengan bobot yang dicapainya. ${ }^{8}$ Penguasaan hasil belajar dapat dilihat dari perilakunya, baik perilaku dalam bentuk penguasaan pengetahuan, keterampilan berpikir maupun keterampilan motorik. Alat untuk mengukur prestasi/hasil belajar disebut tes prestasi belajar atau achievement test yang disusun oleh guru atau dosen yang mengajar mata kuliah yang bersangkutan.

\section{METODE PENELITIAN}

Penelitian ini bersifat survey analitik dengan mengggunakan desain potong lintang (cross sectional) dengan sifat observasional. Populasi dari penelitian ini adalah semua siswa kelas VIII SMP Kr. Eben Haezar 2 Manado sebanyak 163 siswa. Sampel berjumlah 50 orang yang akan dipilih untuk menjadi subjek penelitian berdasarkan kriteria 
yang sudah ditetapkan dengan teknik pengambilan sampel secara acak sederhana (simple random sampling).

Kriteria inklusi pada pengambilan sampel, yaitu siswa kelas VIII, jenis kelamin pria dan wanita, tidak dalam kondisi sakit mata atau cacat mata dan bersedia sebagai objek penelitian sampai selesai dengan menandatangani informed consent.

Penelitian ini menggunakan kuesioner dengan menggunakan pertanyaan terstruktur dan dilakukan pemeriksaan visus untuk menentukan jenis kelainan refraksi. Untuk melihat adanya hubungan antara variabel terikat dan variabel bebas maka digunakan uji Chi Square test dengan tingkat signifikan 5\% $(0,05)$.

\section{HASIL PENELITIAN}

Pada penelitian yang dilakukan di SMP Kr. Eben Haezar 2 Manado didapatkan hasil sebagai berikut:

Tabel 1. Distribusi frekuensi alat bantu penglihatan

\begin{tabular}{ccc}
\hline Karakteristik & f (orang) & \% \\
\hline $\begin{array}{c}\text { Pengguna alat bantu } \\
\text { penglihatan } \\
\text { Ya }\end{array}$ & & \\
Tidak & 5 & 10 \\
& 45 & 90 \\
\hline Total & $\mathbf{5 0}$ & $\mathbf{1 0 0}$ \\
\hline Jenis alat bantu & & \\
penglihatan & & \\
Kacamata & 4 & 80 \\
Kontak lens & 1 & 20 \\
\hline Total & $\mathbf{5}$ & $\mathbf{1 0 0}$ \\
\hline
\end{tabular}

Berdasarkan tabel diatas menunjukkan bahwa responden dalam penelitian ini lebih banyak yang tidak menggunakan alat bantu penglihatan, yaitu sebanyak 45 orang (90\%) dan responden yang menggunakan alat bantu penglihatan jenis kacamata lebih banyak, yaitu sebanyak 4 orang (80\%).
Tabel 2. Distribusi frekuensi pengguna kacamata

\begin{tabular}{ccc}
\hline Karakteristik & f (orang) & $\mathbf{\%}$ \\
\hline $\begin{array}{c}\text { Jenis lensa yang } \\
\text { digunakan }\end{array}$ & & \\
Kacamata lensa minus & - & - \\
Kacamata lensa plus & - & - \\
Kacamata silinder & 1 & 25 \\
Kacamata lensa minus dan & 3 & 75 \\
silinder & & \\
\hline Total & $\mathbf{4}$ & $\mathbf{1 0 0}$ \\
\hline Lamanya menggunakan & & \\
kacamata & & \\
Kurang dari 1 tahun & & 20 \\
1 tahun & 1 & - \\
2 tahun & - & 20 \\
Lebih dari 2 tahun & 1 & 60 \\
\hline Total & 3 & $\mathbf{1 0 0}$ \\
\hline
\end{tabular}

Berdasarkan tabel diatas menunjukkan bahwa responden yang menggunakan kacamata lensa minus dan silinder lebih banyak, yaitu sebanyak 3 orang (75\%) dan responden yang menggunakan kacamata lebih dari 2 tahun paling banyak, yaitu sebanyak 3 orang (60\%).

Tabel 3. Distribusi frekuensi nilai rata-rata hasil belajar terakhir

\begin{tabular}{ccc}
\hline Karakteristik & f (orang) & $\mathbf{\%}$ \\
\hline $\begin{array}{c}\text { Nilai rata-rata hasil } \\
\text { belajar terakhir }\end{array}$ & & \\
$\leq 60$ & - & - \\
$70-80$ & 25 & 50 \\
$80-90$ & 24 & 48 \\
$>90$ & 1 & 2 \\
\hline Total & $\mathbf{5 0}$ & $\mathbf{1 0 0}$ \\
\hline
\end{tabular}

Berdasarkan tabel diatas menunjukkan bahwa responden yang memiliki nilai ratarata hasil belajar terakhir $70-80$ paling banyak, yaitu sebanyak 25 orang (50\%). 
Tabel 4. Distribusi Frekuensi kelainan refraksi

\begin{tabular}{ccc}
\hline Karakteristik & f (orang) & $\mathbf{\%}$ \\
\hline Kelainan refraksi & & \\
Ya & 23 & 46 \\
Tidak & 27 & 54 \\
\hline Total & $\mathbf{5 0}$ & $\mathbf{1 0 0}$ \\
\hline Diagnosis & & \\
Emetropia & 27 & 54 \\
Miopia & 16 & 32 \\
Hipermetropia & - & - \\
Astigmatisma & 7 & 14 \\
\hline Total & $\mathbf{5 0}$ & $\mathbf{1 0 0}$ \\
\hline
\end{tabular}

Berdasarkan tabel diatas menunjukkan bahwa responden yang memiliki kelainan refraksi sebanyak 23 orang (46\%) sedangkan responden yang tidak memiliki kelainan refraksi sebanyak 27 orang (54\%). Responden yang di diagnosis emetropia paling banyak, yaitu sebanyak 27 orang (54\%) sedangkan responden yang di diagnosis miopia sebanyak 16 orang (32\%) dan responden yang di diagnosis astigmatisma sebanyak 7 orang $(14 \%)$.

Tabel 5. Hubungan antara penderita kelainan refraksi dengan prestasi belajar.

\begin{tabular}{cccccc}
\hline Penderita & \multicolumn{4}{c}{ Prestasi belajar } & $\boldsymbol{p}$ \\
\cline { 2 - 5 } $\begin{array}{c}\text { kelainan } \\
\text { refraksi }\end{array}$ & $\leq$ & $70-$ & $80-$ & $>$ & \\
\hline Ya & 0 & 80 & 90 & 90 & \\
Tidak & 0 & 17 & 14 & 1 & 0,0 \\
Total & $\mathbf{0}$ & $\mathbf{2 5}$ & $\mathbf{2 4}$ & $\mathbf{1}$ & \\
\hline
\end{tabular}

Berdasarkan hasil analisis hubungan antara penderita kelainan refraksi dengan prestasi belajar didapatkan nilai $p=0,01$ atau probabilitas dibawah 0,05 ( $\mathrm{p}<0,05$ ). Hal tersebut menunjukkan bahwa penderita kelainan refraksi berhubungan secara signifikan dengan prestasi belajar.

\section{BAHASAN}

Penelitian American Academy of Ophthalmology mengatakan bahwa pengalaman visual anak memainkan peran penting dalamnya perkembangan psikologis, fisik dan intelektual. Gangguan penglihatan karena kelainan refraksi merupakan salah satu penyebab morbiditas yang signifikan pada anak-anak di seluruh dunia. ${ }^{9-11}$

Berdasarkan penelitian Hartanto et al (2010) mendapatkan kelainan refraksi miopia dengan presentasi paling banyak. Penelitian Saw (2003) di Sumatera, Wu di Amerika dan Bastanta (2010) juga menemukan bahwa sebagian besar kelainan refraksi adalah miopia. Penelitian Handayani et al (2011) menemukan bahwa miopia memiliki frekuensi tertinggi pada kelompok umur 1120 tahun (25,1\%). Ini terjadi mungkin karena kelompok usia ini adalah kelompok anakanak sekolah, aktivitas yang lebih tinggi dan pengaruh dari penggunaan komputer. ${ }^{2}$ Sejalan dengan penelitian sebelumnya, pada penelitian ini didapatkan bahwa murid kelas VIII SMP Kr. Eben Haezar 2 Manado paling banyak di diagnosis menderita kelainan refraksi miopia (32\%).

Departemen Pendidikan Nasional (2006) mengkategorikan beberapa tingkatan mengenai penguasaan siswa antara lain, (1) $\geq$ 80-100 dengan kriteria sangat baik yang artinya menguasai hampir semua konsep, (2) $\geq 70-<80$ dengan kriteria baik yang artinya menguasai sebagian besar konsep, (8)60 $<70$ dengan kriteria cukup yang artinya menguasai separoh konsep, $\geq($ (\$) $\quad-<60$ dengan kriteria kurang yang artinya menguasai sebagian kecil konsep, (5) <50 dengan kriteria kurang sekali yang artinya hampir tidak menguasai konsep. ${ }^{12}$ Pada penelitian ini nilai rata-rata hasil belajar terakhir yang paling banyak di raih adalah 7080 (50\%) dan 80-90 (48\%).

Penelitian Lian Hong (2010) melaporkan bahwa anak-anak di sekolah akademis menghabiskan lebih banyak waktu untuk 
membaca dan menulis dibandingkan dengan sekolah regular. Di kelas 1-3, perbedaan waktu belajar bisa sampai 107 menit per hari, dan di kelas 4-6 dan kelas 7-9, perbedaan waktu belajar bisa sampai 160 dan 224 menit per hari. Hasilnya mencerminkan hubungan yang erat antara intensitas belajar dan miopia. Hasil yang sama diperoleh dari penelitian di Singapura (2002), Israel (1993), daerah pedesaan di Cina Utara (2001), Hongkong (1993) dan Orinda (2002). ${ }^{13}$ Pada penelitian ini sejalan dengan penelitian sebelumnya didapatkan responden paling banyak yang menderita kelainan refraksi miopia dengan nilai rata-rata hasil belajar terakhir yang diraih adalah 70-80.

\section{SIMPULAN}

Berdasarkan hasil penelitian dapat disimpulkan bahwa terdapat hubungan yang signifikan antara kelainan refraksi dengan prestasi belajar.

\section{SARAN}

Skrining pada usia pra-sekolah dan sekolah sebaiknya dilakukan secara periodik untuk mendeteksi kelainan refraksi. Kepada orang tua harus lebih peka terhadap kejadian di luar kebiasaan pada anak atau keluhan yang muncul mengenai penglihatan yang terganggu. Tidak melakukan aktivitas melibatkan kerja mata yang maksimal dalam waktu terlalu lama, seperti : membaca, menonton TV, main game, komputer, internet dan lain-lain. Membaca dengan pencahayaan yang cukup dan tidak membaca dalam posisi berbaring. Untuk tetap menggunakan kacamatanya (tidak lepas pakai) bagi yang berkacamata dalam melakukan aktivitas sehingga mencegah atau memperlambat proses bertambahnya minus menjadi lebih tinggi.

\section{DAFTAR PUSTAKA}

1. Ilyas S. Ilmu Penyakit Mata. Ed 4. Jakarta: Balai penerbit FKUI. 2012.

2. Handayani-Ariestanti, T., SupradnyaAnom, I G.N, Pemayun-Dewayani, C. I. Characteristic of patients with refractive disorder at eye clinic of sanglah general hospital Denpasar, Bali-Indonesia Period of 1st January 31st December 2011. Bali Medical Journal (BMJ) 2012; 1(3): 101-107.

3. Resnikof S. 2004 Nov. Global data on visual impairment in the year 2002. Bulletin of the World Health Organization. 82(11).

4. Vitale S, Cotch MF, Sperduto R (2006) Prevalence of visual impairment in the United State. JAMA 295: 2158-2163.

5. El-Bayomi BM, Saad A, choudhury AH (2007) Prevalence of refractive error and low vision among schoolchildren in Cairo. East Mediterr Health J 13: 575-579.

6. Elimination of avoidable visual disability due to refractive error. Report of an informal planning meeting WHO/PBL/00.77.Geneva, WHO 2000, 6-10.

7. David A. Goss, Theodore P. Grosvenor, Jeffrey T. Keller, Wendy MarshTootle, Thomas T. Norton. Optomettric clinical practice guideline care of the patient with myopia. U.S.A.: American Optometric Association; 2006.

8. Vaughan, D. G.2000. Oftalmologi Umum. Edisi 14. Jakarta: Widya Medika. p.401-6.

9. American Association of Pediatric Ophthalmology and Strabismus, American Academy of Ophthalmology. Policy statement: Eye examination in infants, children and young adults by pediatricians. Pediatrics. 2003; 111:902-07. 
10. Ager L. Optical Services for Visually impaired children. J. Comm. Eye health. 1998; 11: 38-40.

11. Global initiative for the elimination of avoidable blindness. 1997. Geneva. World Health Organisation.

12. Almasdi Syahza, Henny Indrawati. Peningkatan hasil belajar mata kuliah manajemen agribisnis melalui pemberian handout pada mahasiswa jurusan manajemen Fakultas Ekonomi
Universitas Riau. Jurnal Sosiohumaniora November 2007; 9(3).

13. Lian-Hong Pi, Lin Chen, Qin Liu, Ning Ke, Jing Fang, Shu Zhang, Jun Xiao, Wei-Jiang Ye, Yan Xiong, Hui Shi, Zheng-Qin Yin. Refractive Status and Prevalence of Refractive Errors in Suburban School-age Children. Int $J$ Med Sci 2010; 7(6): 342-353. 